\title{
EVROPSKÉ SESKUPENÍ PRO ÚZEMNÍ SPOLUPRÁCI JAKO ZPƯSOB PŘESHRANIČNÍ REGIONÁLNÍ SPOLUPRÁCE V RÁMCI EVROPSKÉ UNIE
}

\section{EUROPEAN GROUPING OF TERRITORIAL COOPERATION AS A WAY OF CROSS-BORDER REGIONAL COOPERATION WITHIN THE EUROPEAN UNION}

\author{
ING. JIŘí DUŠEK, PH.D. \\ Katedra managementu a marketingu služeb $\mid$ Management and Marketing Services Department \\ Vysoká škola evropských a regionálních studii, o.p.s. $\mid$ College of European and Regional Studies \\ $\square$ Žižkova 4/6, 37001 České Budějovice, Czech Republic \\ E-mail:dusek@vsers.cz
}

\begin{abstract}
Anotace
Nynějši pojetí regionální politiky jako činnosti, jejímž úkolem je přispivat ke snižováni disparit mezi úrovnémi rozvoje jednotlivých regionů a zabezpečováni jejich harmonického rozvoje, zdůrazñuje $i$ vyžaduje nutnost spolupráce měst, obcí, mikroregionů a regionů při rozvoji daného prostoru. Lokální iniciativa tak ziskává větši a větši význam a stává se za určitých podminek klícovým faktorem regionálního rozvoje. Tento přispěvek se zabývá analýzou Evropského seskupení pro územní spolupráci, nové formy přeshranični spolupráce v rámci Evropské unie. Hlavním cílem př́spěvku je analyzovat historický vývoj této spolupráce $v$ obecné rovině a popsat jeji konkrétní podobu na príkladu Evropského regionu Dunaj-Vltava.
\end{abstract}

\section{Klíčová slova}

Evropské seskupeni pro územni spolupráci, mikroregion, přeshranični spolupráce, regionální rozvoj, spolupráce

\section{Annotation}

In the current concept of regional politics as an activity, the main purpose of which is to reduce disparities in development of individual regions and to ensure their harmonious development, emphasis is also laid on cooperation of towns, municipalities, microregions and regions in development of a given area. Local initiative thus gains more and more on significance and under certain circumstances becomes the most important factor in regional development. The paper deals with an analysis of European Grouping of Territorial Cooperation, new form of cross-border cooperation in the European Union. The main objective of the submitted contribution is to analyse historical development of this cooperation at the general level and describe its particular form on the case of European Region Danube-Vltava.

\section{Key words}

European grouping of territorial cooperation, cooperation, cross-border cooperation, microregion, regional development

JEL classification: $R 11$

\section{Úvod}

Pod pojmem regionální rozvoj si lze představit velký počet různých věcí, stejně jako pod pojmem regionální politika. Obecně ji můžeme definovat jako soubor cílů, opatření a nástrojů vedoucích ke 
snižování př́iliš velkých rozdílů v socioekonomické úrovni jednotlivých regionů, různí autoři se však liší v odpovědnosti a rolích jednotlivých aktérů regionálního rozvoje. Aby se však mohl jakýkoliv region dlouhodobě úspěšně rozvíjet, je zde velice důležitý prvek spolupráce.

Spolupráce je jako vztah založený na dobrovolnosti, nelze proto najít jeden univerzální model, stejně tak jako komplexně vyřešit všechny vztahy mezi jednotlivými aktéry spolupráce. Je také významným vztahem ve všech oblastech lidské společnosti. Velice zásadní věcí je, aby všichni aktéři našli takový systém spolupráce, který jim umožní co nejlépe dosáhnout stanovených cílů. Zlepšování jednotlivých prvků spolupráce je dlouhodobý proces, který vede $\mathrm{k}$ podpoře rozvoje jednotlivých regionů. Umožňuje lepší a účinnější cestu, jak dosáhnout potřebných výsledků, na druhé straně je skutečností, že spolupráce není možné $\mathrm{z}$ různých důvodů $\mathrm{v}$ řadě případů vůbec dosáhnout.

$\mathrm{V}$ posledních letech došlo a dochází $\mathrm{k}$ významným společenským a ekonomickým změnám. V kontextu globalizačních a integračních procesů ve světové ekonomice se zároveň mění úloha substátních územních celků, které sehrávají stále významnější úlohu. Jedním z projevů změn je také to, že se úkoly a kompetence $\mathrm{v}$ oblasti místního a regionálního rozvoje přesouvají na místní a regionální instituce. Otázka místního a regionálního rozvoje tak přestává být výlučnou záležitostí centrálních vlád a stává se úkolem nižších správních orgánů. Obce, města, nejrůznější místní anebo regionální společenství již nejsou pouhými pasivními př́ijemci rozhodnutí investorů anebo centrálních orgánů veřejné správy, ale stávají se aktivními činiteli (skutečnými aktéry) rozvojových aktivit a strategií (Ježek, 2008).

Spolupráce je obecně považována za nástroj nejen kompenzace problémů spojených s velikostí regionu, ale za nástroj schopný vyvažovat také globalizační tendence zasahující i lokální úroveň veřejné správy a politiky (Vajdová, 2006). Tento proces spolupráce začal v ČR v 90. letech 20. století. Obce se jako samostatné a samosprávné jednotky začaly pozvolna spojovat a sdružovat do spolupracujících seskupení různých typů na bázi teritoriální i sektorové. Některá seskupení mají území v jednom okrese, některá hranice okresů překračují; některá sdružují několik obcí, některá téměř všechny obce celého kraje. Současná situace v ČR tak ilustruje dávné zjištění, že místní vlády mají přirozený sklon uchýlit se ke vzájemné spolupráci, aby překonaly své slabosti a vyrovnaly se se svou nedostatečností, která obvykle pramení z malé velikosti obce (Leemans, 1970).

Pro podrobné členění způsobů a forem spolupráce bylo v rámci tohoto př́íspěvku využito členění dle Galvasové (2007), která rozlišuje následující čtyři formy spolupráce:

- meziobecní spolupráce na regionální úrovni,

- spolupráce se subjekty území,

- národní struktury spolupráce obcí,

- spolupráce s obcemi jiných států.

V rámci využití tohoto členění lze namítnout, že je zaměřeno primárně na spolupráci měst a obcí, na druhou stranu se tyto organizační struktury zaměřují i na jiné subjekty než jsou města a obce, jako jsou např. právnické osoby apod. Potřeba vytvořit, udržet a rozvinout optimální podmínky pro uskutečňování rozvojových záměrů obcí či regionů se dlouhodobě opírá o hledání vhodných zdrojů vnitřních i vnějších. Nejvíce chybí vlastní zdroje, a to jak personální, tak i materiální a zejména finanční. Nedostatek finančních prostředků se objevuje jako jeden z nejčastěji deklarovaných problémů, podmiňujících další rozvoj obcí a regionů. V období po vstupu České republiky do Evropské unie se otevřely významně větší možnosti pro získávání „externí“ podpory k realizaci rozvojových záměrů obcí i regionů, současně však narostly i nároky na připravenost a schopnost zainteresovaných subjektů je využít pro zajištění kvalitních rozvojových projektů s pozitivním dopadem na úroveň socioekonomického vývoje daného území. V novém plánovacím období jsou více upřednostňovány „finančně větší “ projekty s tzv. nadobecním či nadregionálním dopadem. Př́íprava takových projektů již vyžaduje kromě většího množství disponibilních prostředků na spolufinancování i rozvinutí úzké spolupráce více subjektů (Galvasové, 2007). 


\section{Obr. 1: Schéma členění způsobů a forem spolupráce}

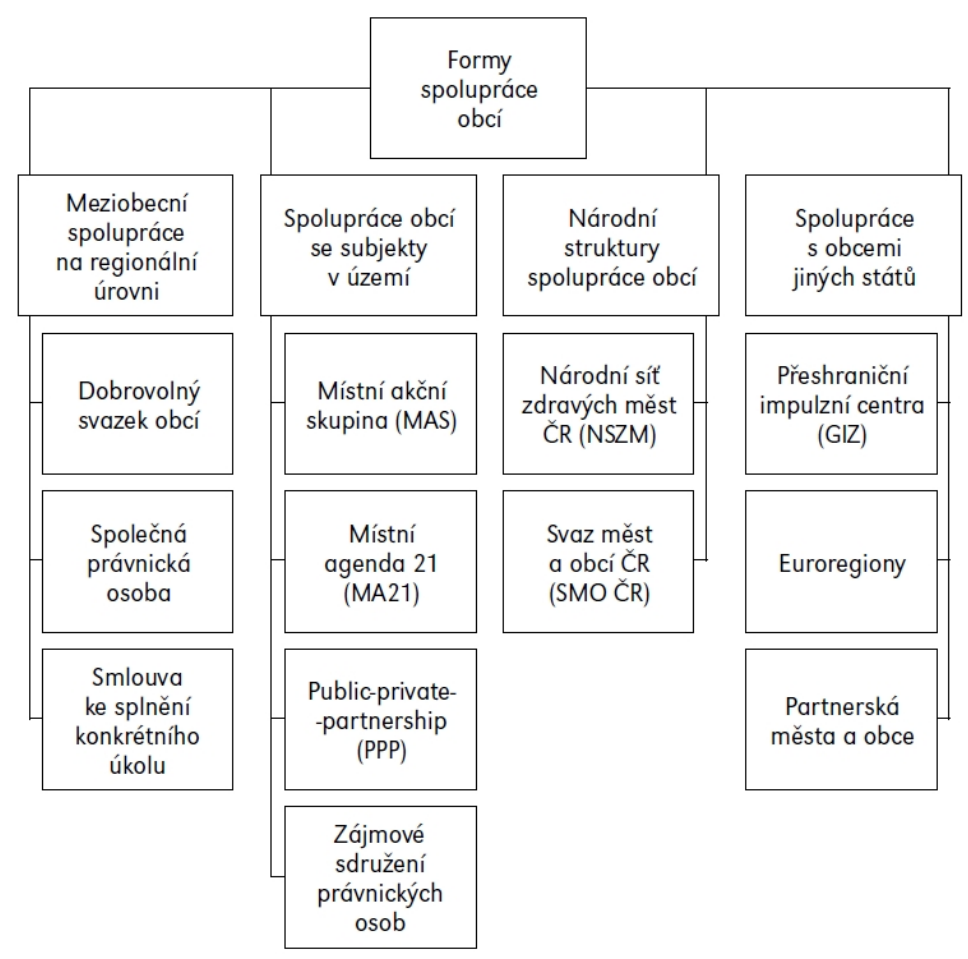

Zdroj: Galvasová, 2007

\section{Cíl a metodika}

Hlavním cílem př́spěvku je analyzovat historický vývoj nové formy přeshraniční spolupráce (tzv. evropské seskupení pro územní spolupráci) v obecné rovině a popsat její konkrétní podobu na př́kladu Evropského regionu Dunaj-Vltava. Metodika předkládaného příspěvku odpovídá metodám vědeckovýzkumných prací, je založena na využití nejnovějších teoretických poznatků na základě studia odborné literatury, odborných výzkumů a studí́, časopisů a materiálů jednotlivých aktérů regionálního rozvoje, na hledání a hodnocení vzájemných vztahů a souvislostí, které přispívají $\mathrm{k}$ objasnění řešené problematiky a odvození a formulování adekvátních závěrů, které vyplývají z této analýzy. V rámci analýzy byl proveden i vlastní průzkum a komparace $\mathrm{v}$ oblasti počtu ESÚS, aby byla verifikována oficiální statistická data uvedená v rámci „EGTC Monitoring Report 2012“.

\section{Formy přeshraniční spolupráce}

V rámci přeshraniční spolupráce se lze v ČR setkat nejčastěji s následujícími formami spolupráce:

a) Přeshraniční impulzní centrum (GIZ)

- Myšlenka zakládání přeshraničních impulzních center se zrodila v Rakousku, kde také začala vznikat jejich první působiště. Cílem bylo vybudovat sít' center podél celé hranice. Původně tak bylo možné najít impulzní centra $\mathrm{v}$ př́hraničních mikroregionech Dolního Rakouska, ČR, Mad'arska a Slovenska (Městský úřad České Velenice, 2011). Pohraniční regiony tradičně patří $\mathrm{k}$ hospodářsky nejméně rozvinutým oblastem každého státu. $Z$ historie si navíc zpravidla nesou břemeno národnostních konfliktů táhnoucích a utlumující rozvoj ekonomických aktivit všeho druhu. $\mathrm{V}$ rámci Evropské unie se proto pohraniční regiony staly rychle místem výměny zkušeností a centrem intenzivní spolupráce při řešení problémů daných zeměpisnou polohou na periferii jednotlivých států.

- Přeshraniční impulzní centra začala masivně vznikat po roce 1989, kdy vznikla nová př́iležitost spolupráce s Českou republikou, největší boom nastal okolo roku 2004, kdy se ČR stala členem EU, což umožnilo finanční podporu těchto center nejprve z programu CBC Phare, později přeshraniční impulzní centra pracovala díky finanční podpoře programu Interreg IIIA, jehož 
následovníkem byl projekt „M00035 - Založení hospodářské platformy Euroregion Silva Nortica“, který fungoval do června 2011 a navazoval na Interreg IIIA. Důsledkem toho rakouské GIZy postupem času zanikaly tak, jak jim končila finanční podpora, z níž byly financovány a placeni jejich manažeři. $V$ současné době je tak již díky ukončení činnosti kanceláŕí, mailů i WWW stránek obtížné jakkoliv mapovat jejich vznik a historii fungování. Na české straně dnes fungují již jen 3 impulzní centra v Českých Velenicích, Slavonicích a Nové Bystřici a je velmi reálné, že minimálně dvě z nich v blízkém horizontu také zaniknout díky tomu, že skončí povinná pětiletá udržitelnost projektu.

b) Euroregiony

- Euroregiony vznikají zejména v př́hraničních regionech. Důvodem jejich vzniku je významná geografická izolovanost a zrretelné rozdíly $\mathrm{v}$ hustotě obyvatel, $\mathrm{v}$ hospodářských parametrech, $\mathrm{v}$ infrastruktuře a dalších charakteristikách. Význam euroregionů spočívá v růstu příležitostí pro iniciaci a podporu lokálního a regionálního rozvoje periferních oblastí. Tato forma spolupráce je přeshraniční spoluprací místních či regionálních samospráv nejen mezi zeměmi EU, ale také mezi členskými a nečlenskými zeměmi. Je to sdružení spolu přímo sousedících subjektů na opačných stranách hranic alespoň dvou států. Může se jednat o obce, kraje (regiony), či jejich sdružení a další právnické osoby. Spolupráce zasahuje do všech oblastí života občanů na kulturní, sociální, hospodářské a infrastrukturní úrovni (Kadeřábková, Khendriche Trhlínová, 2008). ČR se v současné době aktivně zapojuje do 14 euroregionů, jejichž definice vychází $\mathrm{z}$ definice Rady Evropy v tzv. Madridské dohodě.

c) Partnerská města a obce

- Poslední hojně využívanou formou přeshraniční spolupráce je regionální spolupráce na úrovni měst a obcí - nejen na evropské, ale i světové úrovni. Nejčastějšími cíli spolupráce jsou konzultace a přenos poznatků v oblasti veřejné správy, kulturní a společenské spolupráce, výměnné pobyty, spolupráce $\mathrm{v}$ oblasti dopravy, územního plánování a podpory cestovního ruchu. Zcela zvlášst pak stojí spolupráce s obcemi jiných států v podobě tzv. spráatelených měst. Rozdíl spočívá $\mathrm{v}$ absenci jakékoliv uzavřené dohody a jde tedy o spolupráci spíše př́ležitostnou, v některých př́ípadech i jednorázovou bez dalších vazeb.

\section{Nová forma přeshraniční spolupráce - Evropské seskupení pro územní spolupráci}

„Je třeba prìjmout opatření ke zmirnění závažných obtiží, jimž členské státy, zejména regionální a místni orgány, čeli při prováděni a ř́zení činností v souvislosti s územni spoluprací v rámci rozdilných vnitrostátnich právnich předpisů a postupư.... Zvláště s ohledem na větši počet pozemních a námořních hranic Společenstvi po jeho rozšiřreni je nutné usnadnit posilováni územni spolupráce ve Společenství.... " (úvodní ustanovení Nařízení Evropského parlamentu a Rady (ES) č. 1082/2006 ze dne 5. července 2006 o evropském seskupení pro územní spolupráci, Evropský parlament, 2006).

Z důvodů potřeby posílení evropské územní spolupráce (přeshraniční, nadnárodní i meziregionální), která patří $\mathrm{k}$ prioritám Evropské unie, a pro překonávání překážek v podobě rozdílných vnitrostátních právních předpisů, které této územní spolupráci brání, Evropský parlament a Rada Evropské unie schválily v červenci 2006 nařízení, které umožňuje členským státům, regionálním či místním orgánům a veřejnoprávním subjektům $\mathrm{z}$ území různých členských států EU zakládat seskupení s právní subjektivitou - tzv. „evropská seskupení pro územní spolupráci“ (ESUS; anglicky European grouping of territorial cooperation - EGTC). Takové seskupení získává právní subjektivitu, a to podle práva státu, v kterém má dle dohody svých členů sídlo. Díky této právní subjektivitě může uzavírat smlouvy, mít majetek či své zaměstnance. Seskupení by také mělo být schopno realizovat programy nebo projekty územní spolupráce spolufinancované Evropskou unií. Nařízení o ESÚS vstoupilo v platnost 1. srpna 2007 a povinností všech členských zemí EU bylo přijmout národní prováděcí legislativu, která by umožňovala taková seskupení utvářet (Euroregion Silesia, 2013). Začátkem června 2009 byla zveřejněna ve Sbírce zákonů (pod č. 154/2009 Sb.) novelizace zákona č. 248/2000 Sb., o podpoře regionálního rozvoje, ve znění pozdějších předpisů, která upravuje podmínky pro fungování evropských seskupení pro územní spolupráci v podmínkách České republiky. 
ESÚS představují novou možnost uskutečňování přeshraniční regionální spolupráce $\mathrm{v}$ době, kdy kohezní politika obecně a regionální spolupráce obzvláště prochází významnými změnami. ESÚS jako jeden ze tří cílů regionální politiky EU je novinkou v tom smyslu, že umožňuje vznik seskupení regionálních a místních orgánů z různých členských států, aniž by předtím bylo třeba podepsat mezinárodní dohodu a ratifikovat ji národními parlamenty. Členské státy však musí dát svůj souhlas s účastí členů ze svého území (Evropská komise, 2013). Smyslem evropských seskupení pro územní spolupráci je usnadnit a podpořit přeshraniční, nadnárodní nebo meziregionální spolupráci mezi jeho členy za výhradním účelem posílení hospodářské a sociální soudržnosti. Seskupení může sdružovat členy nacházející se na území nejméně 2 států EU a mohou jimi být státy, regionální a místní orgány a veřejnoprávní subjekty (Ministerstvo pro místní rozvoj ČR, 2012).

\section{Obr. 2: Rok přijetí národní prováděcí legislativy Evropských seskupení pro územní spolupráci}

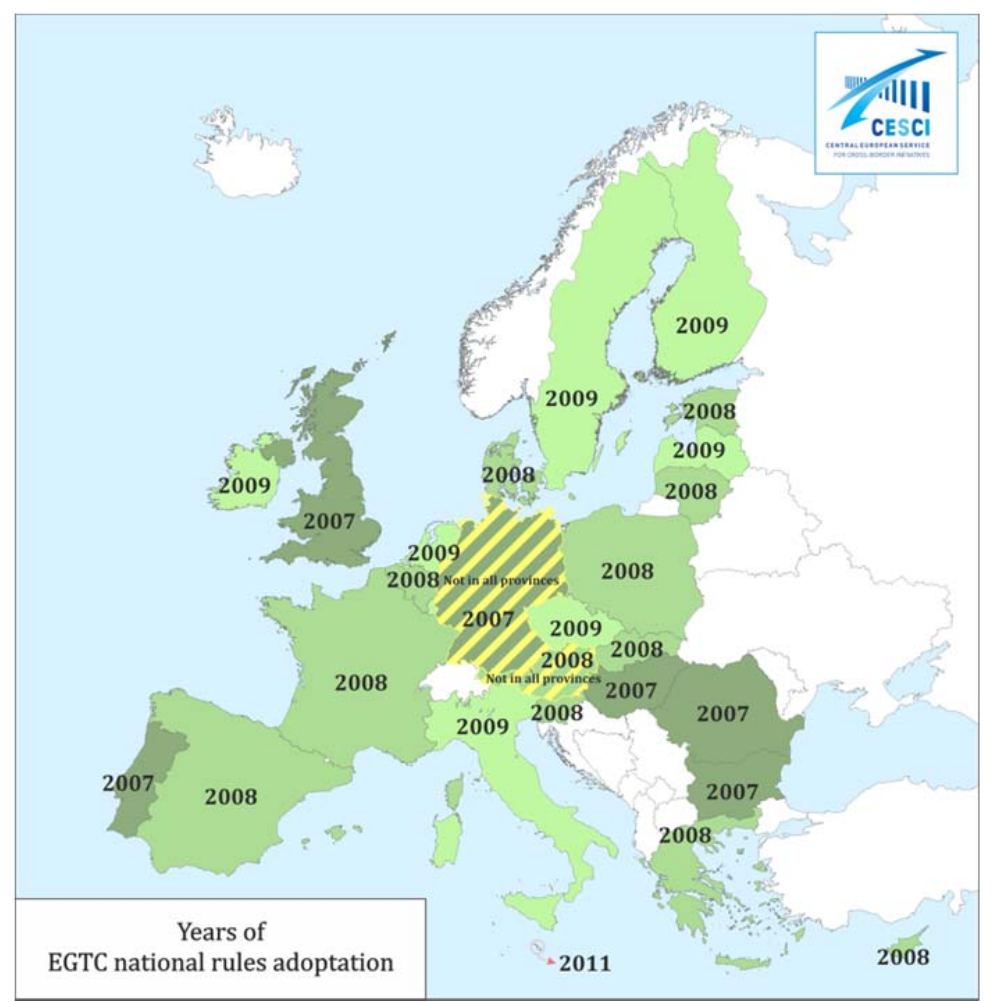

Zdroj: Central European Service for Cross-Border Initiatives, 2009

Celkově se na území EU nachází k 20. březnu 2013 celkem 34 ESÚS, na konci roku 2012 to bylo 32 ESÚS. V průběhu roku 2012 vzniklo 6 nových ESÚS, zatímco u 17 seskupení se vznik teprve připravoval. 32 vzniklých ESÚS zastřešovalo na konci roku 2012 celkem 707 členů z řad národních, lokálních a regionálních orgánů. Průměrná velikost rozpočtu ESÚS je na úrovni $845140 €$, při 5 oficiálně deklarovaných zaměstnancích. 
Obr. 3: Vývoj počtu Evropských seskupení pro územní spolupráci v období 2006-2012

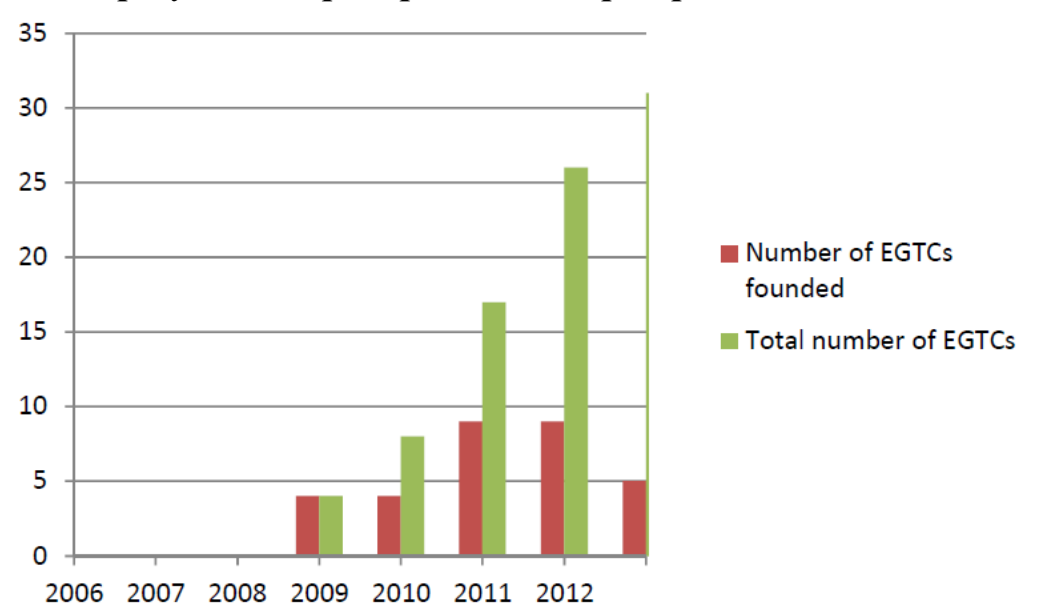

Zdroj: Pucher, Gaspari, Radzyner, 2013

Dle zprávy „EGTC Monitoring Report 2012“ (Pucher, Gaspari, Radzyner, 2013) lze rozdělit z hlediska vzniku a rozvoje ESÚS jednotlivé státy Evropské unie do třech hlavních skupin:

- Španělsko, Francie a Portugalsko,

- Mad'arsko, Slovensko a Rumunsko,

- Francie, Belgie, Německo.

Celkově je pak zapojeno 18 z 27 států EU, mezi nejaktivnější patř́i překvapivě Mad'arsko, společně s Francií a Slovenskem. Mad'arské prvenství bylo významně ovlivněno politikou mad’arské vlády, která podpořila vznik ESÚS různými finančními pobídkami.

Tab. 1: Zapojení zemí Evropské unie do Evropských seskupení pro územní spolupráci

\begin{tabular}{|l|c|}
\hline Mad'arsko & 13 \\
\hline Francie & 12 \\
\hline Slovensko & 9 \\
\hline Estonsko & 7 \\
\hline Belgie & 5 \\
\hline Itálie & 4 \\
\hline Kypr & 4 \\
\hline Německo & 4 \\
\hline Nizozemí & 3 \\
\hline
\end{tabular}

\begin{tabular}{|l|c|}
\hline Portugalsko & 3 \\
\hline Rumunsko & 3 \\
\hline Řecko & 3 \\
\hline Česká republika & 2 \\
\hline Lucembursko & 2 \\
\hline Slovinsko & 2 \\
\hline Španělsko & 2 \\
\hline Bulharsko & 1 \\
\hline Rakousko & 1 \\
\hline
\end{tabular}

\begin{tabular}{|l|l|}
\hline Dánsko & 0 \\
\hline Finsko & 0 \\
\hline Irsko & 0 \\
\hline Lotyšsko & 0 \\
\hline Litva & 0 \\
\hline Malta & 0 \\
\hline Polsko & 0 \\
\hline Švédsko & 0 \\
\hline Velká Británie & 0 \\
\hline
\end{tabular}

Zdroj: vlastni průzkum, 2013

\section{Zapojení České republiky do Evropských seskupení pro územní spolupráci}

Statistiky týkající se zapojení České republiky do ESÚS jsou poměrně rozporuplné a pohybují se v rozmezí 1-3 ESÚS, počtu tři však bylo skutečně dosaženo až 20.3.2013 v souvislosti s registrací Evropského seskupení pro územní spolupráci TRITIA s omezenou odpovědností (ESÚS TRITIA s o.o.), které vytvořil Moravskoslezský kraj společně s Žilinským samosprávným krajem a polskými vojvodstvími Opole a Slezsko. Vznikající region Tritia má téměř stejný počet obyvatel jako celá ČR. Centrem spojení čtyř regionů je katovicko-ostravská aglomerace s osmi miliony obyvatel, sídlo Tritie je Katovicích a Českém Těšíně. Zapojené regiony chtějí prostřednictvím Tritie získat co nejvíce peněz z evropských fondů $\mathrm{v}$ oblasti zelené energetiky, turistiky, dopravy, kulturní výměnu a vzdělávání.

Dále je od roku 2012 Česká republika zapojená do ESÚS Dunaj-Vltava a do European Urban Knowledge Network (EUKN) EGTC.

Česko-rakousko-německý ESÚS Dunaj-Vltava / Donau-Moldau (ERDV) byl založen 30. června 2012. Na Evropském regionu Dunaj-Vltava se podílí: Horní Rakousko, dolnorakouský Most a Waldviertel, Plzeňský kraj, Jihočeský kraj, Kraj Vysočina, Horní Falc a Dolní Rakousko spolu s okresem Altötting. 
Zajímavostí je, že se toto ESÚS neobjevuje ani v „EGTC Monitoring Report 2012“ ani např́klad v Registru evropských seskupení pro územní spolupráci k datu 20.3.2013, což vede autora k oprávněné domněnce, že ustavení ESÚS nebylo oznámeno Výboru regionů Evropské unie podle článku 5 nařízení Evropského parlamentu a Rady (ES) č. 1082/2006. Trilaterální spolupráce má význam pro všechny zúčastněné v různých oblastech. Zejména pokud jde o přeshraniční infrastrukturní opatření nebo o možnosti vzdělávání mládeže. Pro obyvatele by měl evropský region přinést citelný prospěch, a to $\mathrm{v}$ oblasti pracovního trhu díky intenzivnější spolupráci. Od přeshraniční spolupráce se dále očekává $\mathrm{v}$ evropském regionu jednoznačně pozitivní vliv na obyvatele. Některé doposud existující bariéry, pokud jde o spolupráci s lidmi a sousedními zeměmi, by měly být díky spolupráci regionů $\mathrm{v}$ ERDV definitivně odstraněny. Partnerské regiony budou kooperovat $\mathrm{v}$ osmi oblastech budoucí spolupráce. Cílem je vytvořit z evropského regionu atraktivní a hospodářský prostor v Evropě. Každý partnerský region proto převzal vedení nad jednou z 8 vytipovaných tematických oblastí budoucí spolupráce (např. Jihočeský kraj - Mobilita, dostupnost, doprava):

- ERDV jako výzkumný a inovační prostor,

- ERDV - prostor s vysokými školami,

- Spolupráce podniků a tvorba klastrů,

- Kvalifikované pracovní síly a flexibilní pracovní trh,

- Obnovitelné zdroje energie a energetická efektivnost,

- Turistika orientovaná na prírodu, zdraví, města a kulturu,

- Mobilita, dostupnost, doprava,

- Diverzita, jazyk a kultura.

V průběhu prvního pololetí roku 2013 odstartovaly schůzky zástupců jednotlivých vědomostních platforem, jejichž úkolem je promyslet a naplánovat konkrétní opatření v rámci strategie ERDV. Vždy jeden region ERDV přebírá podporu jedné nebo několika vědomostních platforem pro celý ERDV.

V návaznosti na tyto opatření by měly být realizovány různé projekty, pomocí kterých mají být uskutečněny cíle formulované pro oblasti budoucnosti:

- region, kde mají lidé budoucnost,

- atraktivní životní a hospodářský prostor v ohnisku čtyř metropolních regionů,

- silného partnera pro evropskou politiku,

- učící se a dynamický region.

European Urban Knowledge Network (EUKN) EGTC byl založen v roce 2012, registrace 7.12.2012, což je Evropská sít' znalostí městských záležitostí. EUKN je udržitelnou, mezivládní znalostní sítí s národními kontaktními místy ve všech členských státech, působící jako centrum znalostí pro stávající sítě odborníků na urbánní záležitosti na všech úrovních správy. Aktivity sítě EUKN jsou zaměřeny na posílení ekonomické pozice měst prostřednictvím výměny znalostí a zkušeností v urbánní oblasti.

Setkat se lze i s česko-slovensko-mad'arsko-rakouským projektem Centrope, což je název Evropského regionu, který zahrnuje Jihomoravský kraj v Česku, slovenské kraje Bratislavský a Trnavský, západomad’arskou župu Györ-Moson-Sopron (Ráb-Mošon-Šoproň) a Vaš a rakouské spolkové země Burgenlandsko, Dolní Rakousy a Vídeň. Dále jsou přímými členy schůzek Centrope také města Brno, Bratislava, Trnava, Győr, Sopron, Szombathely, Eisenstadt a St. Pölten. Na základě prohlášení z Kittsee z roku 2003 spolupracují na rozvoji evropského regionu na tomto čtyřmezí, nejedná se však o tzv. Evropská seskupení územní spolupráce, která vznikla až po roce 2006.

\section{Závěr}

Evropská seskupení územní spolupráce jsou v současné době dynamicky se rozvíjející formou přeshraniční spolupráce napříč mnoha regiony Evropské unie, o čemž svědčí růst jejich počtu v roce 2012 o $+23,1 \%$ i počet participujících států, přsto zde máme 9 států EU, na jejichž území se žádné ESÚS nenachází. Politické reprezentace si např́íc jednotlivými formami ESÚS (z 32 ESÚS je 15 ESÚS lokálních, 11 regionálních, 2 multiúrovňové a 4 transnacionální) mnoho slibují, zejména v oblasti př́livu finančních prostředků EU, zlepšení dopravní infrastruktury a plánování. Zda nejsou tato očekávání až př́liš optimistická, ukáže další programovací období 2014-2020, protože 
přesměrování finančních prostř̌edků do rozvoje ESÚS by muselo být provedeno na úkor jiné vybrané úrovně NUTS, což nemusí být přijatelné pro prríslušnou politickou reprezentaci. Z hlediska dalšího rozvoje ESÚS jsou tedy rizika zejména finanční, kdy se na příkladu přeshraničních impulzních center v minulosti prokázalo, že ukončením finanční podpory ze strany EU došlo v blízkém časovém horizontu i k postupnému zániku většiny center. Mezi další problémy lze jmenovat chybné statistiky ESUUS napříč jednotlivými orgány Evropské unie, kdy na př́kladu ČR je oficiálně uváděno jen 1 ESÚS, ačkoliv zde byly ve skutečnosti 2 seskupení, jiná regionální uskupení (např. Centrope) zase naopak využívají pojem ESÚS nesprávně, z právního hlediska se v tomto př́ípadě jedná o jiný typ spolupráce. Problematické je i nepřesné používání pojmu euroregion v př́ípadě ESÚS, což může vést k mystifikaci, o jakou konkrétní formu spolupráce se jedná - viz Euroregion Dunaj-Vltava X skutečné euroregiony Silva Nortica a Šumava-Bavorský les. Vzhledem k nejednotnému výkladu, statistickému sledování i dalším nepřesnostem u ESÚS si lze logicky položit otázku, zda bylo tento typ spolupráce opravdu nezbytné řešit novou formou spolupráce či zda nebylo možné využít již stávajících forem spolupráce, stejně jako finančních toků v rámci regionální politiky a plánování.

\section{Literatura}

[1] EGTC (European Grouping of Territorial Cooperation) [online]. Central European Service for Cross-Border Initiatives, 2009 [cit. 2013-04-29]. Dostupné z: <http://cesci-net.eu/egtc $>$.

[2] EGTC / ESÚS - nový nástroj přeshraniční spolupráce [online]. Opava : Euroregion Silesia, 2013 [cit. 2013-04-29]. Dostupné z: <http://www.euroregion-silesia.cz/show_text.php?id=cinnostEGTC-ESUS>.

[3] Evropská seskupení pro územní spolupráci (ESÚS) [online]. Brusel : Evropská komise, 2013, 29.4.2013 [cit. 2013-04-29]. Dostupné z: $<\mathrm{http}: / /$ ec.europa.eu/regional_policy/archive/funds/gect/index_cs.htm>.

[4] Evropská seskupení pro územní spolupráci (ESUUS) [online]. Praha: Ministerstvo pro místní rozvoj ČR, 2012 [cit. 2013-04-29]. Dostupné z: <http://www.mmr.cz/cs/Podpora-regionu-acestovni-ruch/Regionalni-politika/Evropska-seskupeni-pro-uzemni-spolupraci>.

[5] GALVASOVÁ, I., et al. Spolupráce obci jako faktor rozvoje. 1. vyd. Brno : Georgetown, 2007. 140 s. ISBN 80-251-20-9.

[6] Jak vznikla přeshraniční impulzní centra [online]. České Velenice: Městský úřad České Velenice, 2011 [cit. 2013-04-29]. Dostupné z: <http://www.velenice.cz/?c=centrum\&id=jak-vzniklapreshranicni-ic $>$.

[7] JEŽEK, J. Podpora místního ekonomického rozvoje. In Klímová, V. (ed.) XI. mezinárodní kolokvium o regionálních vědách. Sborník přispěvkỉ. Brno: Masarykova univerzita, 2008. s. 320326. ISBN 978-80-210-4625-2.

[8] KADEŘÁBKOVÁ, J., KHENDRICHE TRHLÍNOVÁ, Z. Region a regionální vědy (vybrané sociální, kulturní a environmentální aspekty). Praha: Vysoká škola finanční a správní, 2008. $77 \mathrm{~s}$. ISBN 978-80-7408-009-8.

[9] LEEMANS, A., F. Changing patterns of local government. The Hague: International Union of Local Authorities, 1970. $512 \mathrm{~s}$.

[10] Nařizeni Evropského parlamentu a Rady (ES) č. 1082/2006 ze dne 5. července 2006 o evropském seskupeni pro územní spolupráci [online]. Brusel : Evropský parlament, 2006 [cit. 2013-04-29]. Dostupné $<$ http://ec.europa.eu/regional_policy/sources/docoffic/official/regulation/pdf/2007/gect/ce_1082( 2006)_en.pdf $>$.

[11] PUCHER, J., GASPARI, E., RADZYNER, A. EGTC Monitoring Report 2012. Brussels: European Union, 2013. 130 s. ISBN 978-92-895-0709-7.

[12] VAJDOVÁ, Z., ČERMÁK, D., ILLNER, M. Autonomie a spolupráce: di̊sledky ustavení obecního zřizení v roce 1990. Praha: Sociologický ústav AV ČR, 2006. 108 s. Edice Sociologické studie/Sociological Studies 06/02.

Př́spěvek byl zpracován v rámci interního grantu IGA VŠERS 2/2013, autor je expertem vědomostní platformy „Kooperace vysokých škol“ Evropského regionu Dunaj-Vltava. 